This is the author's final, peer-reviewed manuscript as accepted for publication. The publisher-formatted version may be available through the publisher's web site or your institution's library.

\title{
The Church and peer review: was "peer" review fairer, more honest then than now?
}

Thomas H. P. Gould

\section{How to cite this manuscript}

If you make reference to this version of the manuscript, use the following information:

Gould, T. H. P. (2012). The Church and peer review: Was "peer" review fairer, more honest then than now? Retrieved from http://krex.ksu.edu

\section{Published Version Information}

Citation: Gould, T. H. P. (2012). The Church and peer review: Was "peer" review fairer, more honest then than now? Journal of Scholarly Publishing, 44(1), 36-60.

Digital Object Identifier (DOI): doi:10.3138/jsp.44.1.36

Publisher's Link:

http://utpjournals.metapress.com/content/n661v5r4287h7364/?p=cf70376838b448cf8a2 f46867c8aec65\&pi=2 
The Church and Peer Review: Was “Peer” Review Fairer, More Honest Then Than Now?

Since the $16^{\text {th }}$ Century, seeking approval for one's work has required everything from capturing classic patronage to attaining academic standards. The process of a work's review has ranged widely from having an “insider’s track,” to seeing one’s work rejected for anything but obvious or defensible reasons. What is sought by the academy has always been a method to identify the works that exhibit validity and reliability, perhaps best described as "sound" in design and execution. At its best, peer review is not bound to the status quo, but rather by progress, exhibited either as reaffirmation of an existing thesis, or introduction of a new idea grounded in solid methods and reasoning.

However, what drives the individual academic to create may not match the responsibilities of the academic gatekeepers, whose duties revolve around assuring that what is created is based on best practices. The scientist/scholar wishes to push the boundaries, discover the possible causes for $\mathrm{X}$. The reviewers wish to protect the academic community from bad ideas, unreliable methods, and unsound theories. One group, therefore, is inherently liberal in its thinking, while the latter is routinely more conservative.

The argument for the past twenty to thirty years is that the goals of peer reviewsound, reliable, reproducible research—are noble, but the method of application of academic oversight is corrupt, erroneous, and often no better than chance in its outcomes. The purpose of this paper is to draw a comparison to a time of peer review rarely examined, that being the method applied prior to the 17th Century, to the current system 
in place today and, in doing so, offering that the similarities may provide some counsel to the development of a new form of peer review.

\section{Past Issues, Present Problems}

This history of peer review in the modern era is dotted with research outlining its serious flaws. Perhaps one of the most cited examples involves the research of Peters and Ceci. The authors re-submitted a handful of previously published works to the same journals that had accepted them only a few months earlier. Peters and Ceci substituted fictionist names for the authors and their institutional affiliations. While one of the papers was rejected as a previously published work, three were accepted and eight more were rejected. The rationale for the rejections was, in many of those cases, that the articles contained "serious methodological flaws." As the researchers noted at the time, "a major portion of the criticism of the journal review system has concerned the reliability of peer review." ${ }^{i 1}$ The Peters and Ceci research suggested the high rejection rates of previously published articles might be related to author standing, institutional standing, peer bias, and poor reviewer performance. This was especially apparent given that the researchers could not find any significant changes in the methodological or theoretical standards at the involved publications. The flaws, as noted by the second set of reviewers, were "old and basic notions having to do with such matters as confounding, non-randomization, use of ANOVA with dependent data, subject mortality, and the like. These points were considered flaws a year ago and probably be considered flaws ten years from now."

\section{Gender Bias}


Research published in 2001 suggested that even in a country like Sweden—which ranks low among countries in gender bias—women face a much harder time getting their articles published. Wennerás and Wold examined the way grants were awarded by the Swedish Medical Research Council, a major funding agency of biomedical research in the country. iii In the 1990s, women researchers seeking post-doctoral funding were successful less than half that of male applicants. Was that because the women were perceived as less productive, and, thus, less committed to their work?

What they found was that, in this issue of citation rates where male and female authors produced the same number of published works and had similar citation rates in other articles, the male authors were ranked higher by the review committee. Especially damning was the fact that female researchers had to attain a perfect impact scores of 100 to be considered as competent as the male researchers who scored only 20 total impact points. That is to say, the most productive female researchers were judged only as strong as the bottom quintile of male researchers. The article's authors suggested that to avoid the loss of a "large pool of promising talent," the peer review process needed re-tooling to create "built in resistances to the weaknesses of human nature."iv

\section{Data Theft, Publishing Delays: Stall, Steal, Switch}

The peer review process relies upon not only a fair reading of the material presented by unbiased readers. It also relies upon those readers to keep the informationunpublished as it is when they handle it—private. Research is not only related to tenure and promotion, but also grants—grants that might evolve into millions of dollars of support. Researchers trust that the work they place in the hands of a journal will not be 
siphoned off to others, intentionally or by accident. Data theft is a very serious issue for private industry. It certainly should be of primary concern for scholarly publications and granting agencies.

In February of 2010, 14 stem cell researchers wrote letters to several leading journals in their field complaining that the review process was being high-jacked to benefit others. The controversy involved allegations that reviewers were "deliberately stalling, or even stopping, the publication of new results so that they or their associates can publish the breakthrough first."v Austin Smith, director of the Welcome Trust Centre for Stem Cell Research, noted that "It's hard to believe except you know it's happened to you where papers are held up for months by reviewers asking for experiments that are not really fair or relevant ... a paper in Nature or a paper in Cell is worth your next grant - it could be worth half a million pounds." As noted by Dacey, who reported the controversy on a Physics World blog, being "world first" in a field can set up a first-year professor for life. Having that work quite literally stolen by a reviewer or a friend of the reviewer would not only be outrageous and unfair, it would certainly give the young researcher reason to pause before sending the next breakthrough paper to that journal.

At times the theft is intentional on the part of the reviewer. Other times, it may be completely innocent, as was the case in 1996 with Carolyn Price, a microbiologist at the time at the University of Nebraska at Lincoln. Price, reading through grant applications for the National Institutes of Health (NIH), noticed one that looked very familiar. Pulling out a successful application she had submitted to a state funding agency, she found parts had been used, word-for-word, by a biochemist at the University of Southern California. The connecting agent was a Los Angeles-based reviewer that had been used in the initial 
Price NIH application evaluation process. That reviewer had shared the original work with a friend, Asraf Iman, a USC professor, who then used large portions of it-including the other researcher's specific aims, the background on proposed methods, the experimental design and research plan, and most of the references — in a grant application. $^{\mathrm{vi}}$

Imam's boss at the time noted the "enormous pressures on non-tenured faculty," which is certainly present at all universities. While Iman was punished for substantial use of the wording in the original grant application, he moved on to a job as director of the Molecular Pathology Program at a USC gene therapy research center. ${ }^{\text {vii }}$ This kind of end run around protecting original research sends messages that the ends can, at times, justify any means necessary.

\section{Acceptance Is a Matter of Style?}

In 1977, Mahoney examined the pattern of review by 75 journal reviewers of manuscripts that described identical experimental procedures. Mahoney's intent was to determine if confirmatory bias - the tendency to believe outcomes that matched one's own beliefs and to discount those that do not—guided the peer review process at a selection of scientific journals. Mahoney's work was a follow up to his earlier published work that showed confirmatory bias in scientists.

Mahoney's 1977 work looked at patterns of critiques of various sections of articles by sending only sections of a paper purported to be in the editorial process. The 75 reviewers (drawn from the Journal of Applied Behavior Analysis) were broken up into teams that looked at the introduction, methodology, summary of results, and discussion 
of the finds. The results suggested that reviewers more positively ranked papers with positive experimental outcomes that matched their own beliefs. In addition, the level of agreement among reviewers was low, again suggesting the review process was driven by something other than a critical examination of the work addressed. ${ }^{\text {viii }}$

The bias can be one of preferred methodology. Perhaps one has submitted a paper dealing with the introduction of Western advertising into post-Soviet Russia to a major journal only to be told the methodology used-interviews — was questionable because it was not reproducible. The bias can be one of preferred style, such as making sure that a paper written dealing with legal issues be written in an accepted "legalese" language.

\section{Varied Results: A Game of Chance?}

Neff and Olden in 2006 subjected the issue of "suitability" to statistical analysis and found that the traditional model of one editor and two reviewers generated results that were no different than chance. That is, if an article was submitted for [possible inclusion in a an academic journal, pre-screened by one editor (or no pre-screened at all), then given to two reviewers, the chance that the article would be accepted was close to chance (50-50). However, if more reviewers were used, there was a three out of four chance that suitable papers were accepted. ${ }^{\text {ix }}$ The conclusion was that "the review process can include a strong 'lottery' component, independent of editor and referee integrity." ${ }^{\mathrm{x}}$ In addition, while the research indicated a stronger likelihood that unsuitable articles would be rejected when three reviewers were involved (instead of two), it also indicated a higher likelihood that more suitable articles would be rejected. The authors also found that the strength of the publication process could be weakened significantly by what they 
called the "repeated submission" syndrome. Articles rejected by one publication stood a better chance of being accepted either by the same journal on resubmission, or by another journal not necessarily possessing a lower impact value. This is especially disturbing, given that the peer review process is supposed to reflect the robust quality of the work, not the endurance of the researcher.

Resistance to Change: The Status Quo Is a Good Thing

We have tracked the faults in the peer review process in areas of bias, theft, and random chance. Perhaps the most predictable issue—and the one that has been in the background the longest, in one form or another—still to be dealt with is the resistance of the academy itself to new ideas. The Church resisted scientific explanation for the paths of the planets. Rulers resisted research that promoted a rival's nation's standing. It follows that scientists could be equally guilty of the most human of all weaknesses: egotism.

Campanario, in 2009, published research that traced the failures of Nobel Laureates as they attempted to publish the very works that would lead to their success. And, as Campanario notes, little has been published on these failures. ${ }^{\text {xi }}$

It is an axiom of science that all research should be treated with a degree of openmindedness, a trust that all research should be judged on its merits, not on whether it "fits" the current norm. So when a new idea is rejected de facto, or, even worse, when a researcher with new ideas is silenced and shunned, it is science itself that stands to lose. As Planck noted, "A new scientific truth does not triumph by convincing its opponents and making them see the light, but rather because its opponents eventually die, and a new generation grows up that is familiar with it." ${ }^{\text {xii }}$ Eventually the old dogs die and a new idea 
has a chance, whether it is an odd theory of relativity dreamed up by second-level patent clerk Einstein or a complex mathematical equation devised by Avogadro.

Companario catalogued 24 submissions by Nobel Laurates, submissions that "encountered resistance on the part of scientific editors or referees."xiii These were the very same works that would, eventually, earn their creators a Nobel Prize. In other cases, such as that of Allan Cormack, research is published, then ignored for as much as a decade before being "discovered" by the academia community. Companario is generous in his criticism of the peer review process, suggesting that, in some cases, an initial rejection by a journal editor leads to a stronger product from the researcher. In some cases, the peer reviewers simply lacked the ability to appreciate what was being presented (we've always suspected that regarding the tardiness in accepting Einstein's Theory of Relativity). In other cases, these new ideas "clash with orthodox views held by the referees." ${ }^{x i v}$ However, on the whole, he notes, the "outcome of peer review raises important questions about current publishing policies which govern the dissemination of information." ${ }^{\mathrm{xv}}$ Companario notes that, perhaps, "Scientists who challenge dominant paradigms should be prepared to face skepticism and rejection."

\section{The Sword Hanging Above Scientific Research}

The issue of fairness and accuracy in peer review is of particular importance these days as we face the possible total circumvention of the peer review process as exemplified by eReserves. Lacking a reliable, unbiased, and ethical system of review, authors may simply choose to post their works directly online (as many have already chosen to do). Perhaps, as part of our examination of possible solutions (given that stasis 
may not work), we might consider the very nature of peer review itself, starting with its earliest manifestations.

\section{Where we are today}

The balance that pits a researcher's incessant quest for new ideas and solutions via science-based fact-finding methods and sound thinking against an editor's need to protect scholarship and, by doing so, preserve a journal's reputation. The researcher seeks recognition by way of a new idea or new way of looking at an existing issue. The editor seeks to underscore the journal's reputation for publishing only sound and additive material. This focus on protecting a journal's reputation can, at times, results in a conservative view, one that places more trust in the replication of what is already known and accepted. This has never been a happy marriage between ambition (often posed as "academic freedom") and reputation (often posed as "academic accuracy.").

As the sense of academic security (an operationalized factor for "accuracy") increases, the ability of journal editors to accept new ideas, whether in the arts or sciences, decreases. To attain perfect accuracy is to deny any academic freedom (as expressed as new ideas, "radical" ideas). We have periods of great scientific advances, usually described some decades or centuries later as Golden Ages, typically reliant on benign despots. We have darker periods, where science is held is disrespect and academia threatened. These are periods of societal pushback. It is a given that the default path is to cling to the past, to the known, to the safe. This is hardly a new idea. Whether we consider the circumstances surrounding the death of Socrates or, more recently, the challenges facing societies such as those within Maghreb, ${ }^{\mathrm{xvi}}$ the issue of balance between 
what the society demands from science and what science expects from society has been debated for centuries. Thankfully we no longer expect our wayward academics to become familiar with hemlock, except metaphorically, perhaps. Yet, we may be just as powerful in our rejection of the unfamiliar, whether it be a style of writing (for example, lawyers write for lawyers and suspect any scholarly writing not offered in their special language), or a new area of science that challenges our core beliefs (global warming springs to mind). As noted by Chubin and Hackett:

Analysts of peer review at times are blinkered by the powerful values that make up the cultural context of science, and are unable or unwilling to notice that science operates imperfectly. ${ }^{\text {xvii }}$

The argument can be made (and has been made) that, in some ways, the role within the church's "peer review" system for cleric reviewers and editors prior to the 16th Century was to smooth not only the rough spots of grammar and syntax within a work, but to mollify the researcher's more powerful statements and conclusions. ${ }^{\text {xviii }}$ The common belief is that this conservative tendency to restrict new ideas occurred more frequently in the centuries prior to the creation of modern peer review in the Seventeenth Century. A system of academic research did, in fact, exist in the period prior to the advent of the modern academic journals, the two first of these generally accepted to be Journal de Sçavans and Philosophical Transactions, both created in early 1665. And, with this academic research, a form of peer review also existed.

\section{The Deeper Sources of Peer Review}


Attempting to describe how works were reviewed prior to the rise of the academy might seem both fruitless and of little importance. After all, we have a sufficient experience with peer review over the last four centuries. We hardly need to look back further to understand the process.

I disagree. To fully understand peer review and its importance in scientific research — as well as map a way forward —we must consider its deepest foundations. Peer review did not spring whole out of thin air simply because we had the ability to print more efficiently and far more quickly. The justifications that remain with us today for a system that most accept as flawed are more than a set of rules: they represent that need within society to protect itself. The risks associated with new ideas are weighed within all societies against the potential benefits that might be derived. Over time, or so the thinking might go, the more secure we feel, the more willing we are to allow for more radical thinking to be published and shared. Thus, rather than starting with the peer review we are familiar with, that of scholars sitting in judgment of scholars, we must look back further and consider the method in which academic research was reviewed and by whom. We must, of course, accept that much of what will follow is based on the thinnest concrete of proof, but rather flows from a critical examination of the church's relationship with the scholars that did exist in the first millennium.

Scientists prior to the rise of the academy typically relied on the support and approval of the church, which, in turn, maintained a tenuous relationship with secular states: some closer (Italy and Spain), some looser (England and the German states). It is a mistake-as few do - to believe that all science started with the Enlightenment, just as it is a mistake to believe the Dark Ages were wholly dark. And, perhaps most important, it 
would be a grave error to assume that whatever system of peer review existing before the rise of academic journals has little to do with how we conduct peer review today. We can trace back to the earliest writings a single thread of control, whether by the church or the crown, that would delay or completely eliminate works found counter to established belief (aka: Science). The actions were, no doubt, justified at the time as protecting society from "wrong" thinking. The exclusion of these "wrong" ideas was further justified as necessary to maintain a corps of belief that bound societies together.

\section{"Peer" Review before 1600}

The field of humanities has long relied upon its peers - typically called critics—to weigh the value of new works, whether they are paintings, film, or poetry. One can imagine a caveman, proud of the realistic rendering of a recent deer hunt on a cave wall, looking to fellow friends in his grotto for approval and appreciation. Plaudits would lead, to higher standing within the tribe, which might include all sorts of rewards in itself: perhaps a better seat at the table, for starters. This is not to suggest that approval by one's peers of a recently created work is its only reward. Certainly the need to provide an outlet for one's inner creativity, the need to catalogue one's societal history, and the need to interpret a people's culture can drive the creator. Yet, the need for affirmation, whether one that leads to tenure and promotion or just heightened status in the tribe, may be the most common and most powerful driving force behind the need to create.

It is a classic argument: what came first, the text or the critic? One would presume the former: after all, who needs a critic if there is no text? But such a conclusion may be no more than semantics. A societal structure that starts with the massing of power within 
a handful of individuals could (and did) exist prior to the rise of scholarship. If peer review were cast as an effort to control the distribution of information, a king or archbishop would suffice to fill the bill. Put this way, peer review certainly existed—in some form—-far earlier than the appearance of schoolmen in Bologna and Paris in the 12th Century or the birth of intellectuals, as described by Le Goff. ${ }^{\text {xix }}$ Yet, we know little of the procedures used, the standards required, or the consequences of failure associated with this peer review. Yet, we know far more about the authors of the Dark Ages in Europe than we do their "readers." The works of Gregory the Great, Bede, Gallus, Alcuin, Theodulfus ... and many more authors of the Dark Ages could not have been known far and wide in the periods of their appearances. But these authors are (and were) known far more widely than the powerful men who sanctioned their works and provided both political and social cover.

We may be ignorant of the personalities involved, yet we do know some elements of the publishing world of the Dark Ages. We know books were extremely expensive. We know that few could read their contents. We know that the church held sway over the vast majority of what would be published, including the early suppression of some existing works (such as that of Aristotle) and the dissemination of others (such as the Vulgate Bible). The literate society of Europe at those times had to be small, almost a club of intellectuals (elites?) working within somewhat known constraints. And we can only assume the impetus for these authors was more than mere income or even station within their societies. But we also know that few, if any, books were published without first receiving an affirmative review by those in power. 
Whatever the source and nature this intense need for approval, authorship relied as it does today, in large part, on the concept of the creator as an individual, an idea that did not exist to any large extent prior to the Renaissance. One might trace this act of individuation back to the authors of the Dark Ages mentioned above, or continue further back to the authors in Rome and Athens. Whatever the source, the author as an individual as evidenced in creative works is also proof of the present of some independent thought. While the amount of such independent thinking must have been very small in the 6th Century, it is certain that it was present in the 12th Century. This independent thinking, this desire to improve upon current ideas, also suggests a willingness to, literally, go it alone, to metaphorically walk away from existing beliefs held by a community, church or nation state.

The very idea of an individual existing separate from the community—previously suppressed by the caste system in the dying days of the Roman Empire-was outlawed in all its forms by the Catholic Church in the period leading up to the 12th Century. ${ }^{\mathrm{xx}}$ The foundation of the feudal system that reigned in the first millennia relied on the complete sublimation of a "person" as anything more than an object, a piece of property, ownedliterally body and soul—and told what to think and do by those higher on the sociopolitical-economic ladder. Christianity and governmental fiefdoms throughout Europe considered the idea of personal beliefs to be "identical with arrogance, rebellion, and sin. Medieval Christianity restricted individual expression, fostered self-abnegation and selfannihilation, and demanded implicit faith and unquestioning obedience."xxi

Starting from that rejection of the idealized form of the individual—be that person considered a scientist or witch-any act of non-group thinking was considered heresy, at 
best, and treason, at worst. And, though neither was likely to result in severe punishment (a simple recant was all that was usually required), any person known as a "free thinker" was hardly a positive reference to those in power. Some cases, such as that of Cecco in the 14th Century, resulted in a burning. But many more were resolved with a confession and recanting. ${ }^{\text {xii }}$ But the Church's interest in maintaining a degree of orthodoxy was more about keeping the flock in line versus permanently weeding out errant sheep. The path was always open to those with scientific yearnings to express themselves, then await judgment from those higher up the ecclesiastical chain. We have no clear picture of exactly what the procedures involved included. We do know that some scholarly work was found lacking after publication. This infrequent post-publication pattern of review might suggest that some works were examined prior to publication, though we have little proof of this.

The crux of the hand is that the system of judgment of a work was made after the document was made "public"—-keeping in mind the limited number of people who could both access the document and then actually be able to read it. We do not know of suppressed writings that have never seen the light of day. However, we are familiar with those works which, once published, were recanted, removed, or eliminated. What the church (and others) practiced, at least in part, was "post" review, examining a works after it had been made public. This act of examining the work after publication represents at least one of the possible solutions to our present day peer review. In at least this way, the church was acting less conservative and more open than we are today. That is, a work was allowed to be known, if only for a short time, rather than suppressed prior to publication. Authors could expect an examination by clerics; but they could also expect 
examination by their peers. If the church were motivated by the same logic that drives peer review and pre-publication suppression today, it would have assured that all works were reviewed prior to their being made public. The opposite was at least part of the church's routine, perhaps driven by geography and in part by the limited number of readers.

This systematic attempt to maintain a lock on the individual—perhaps visualized as a free person—continued with the rise of city states: the value of the citizen was the contribution he (or, to a lesser degree, she) made to the community. Any acts of what we would now call individuality were seen as not only dangerous, but sufficiently treasonous to warrant immediate suppression, either by some form of recanting or the forcible ejecting of the offender from the community. These acts of punishment were purely an effort to protect the community from radicalism, which easily could push a city-state or nation into anarchy. The Dark Ages were, after all, dark, quite literally, and any venturing outside the community gates into the Wide World—as described by Kenneth Grahamewas an invitation to lose one's head to some roving gang of rogues (a.k.a., stouts).

Of course, some information required suppression. The justification of censorship in the ninth century was, oddly, very similar to the logic applied today in rejecting a perceived poor work of scholarship: we must protect the community's "soul" from bad, possibly dangerous, ideas. The effort took many forms in these early centuries in Europe, starting with the mechanisms employed by what was probably the best organized defender of the "truth"—or the established status quo—at the time, the Church. Through a system of clerics and an absolute devotion to the Rule, ${ }^{\text {xxiii }}$ clerks of the papacy not only 
acted as the keepers of knowledge, but also played secular various roles within the communities that dotted Europe in the first millennium.

But, keep in mind, the scriptoria - that class of clerks and monks within monasteries carefully copying one book into another-did so not as an act of creation, even though these documents were often lavishly decorated with artful illumination. Theirs was an act of faith, an effort of shave off time of the time they would spend in purgatory. And, yet, if only by accident, it was their efforts in copying the great works of long deceased authors of Athens and Rome (as well as authors such as Martianus Capella) that made the Renaissance of the 12th Century possible. ${ }^{\text {xxiv }}$

In "Intellectuals in the Middle Ages," Le Goff lays out an argument that proposes to connect the appearance of the Western Scholar to the rise of communities. These communities, usually small, were traditionally protected to some degree by walls and their particular clerical order. And, while archbishops were coveted by a community as a sign of power, so were scholars. While not directly addressing the case for individuality, Le Goff does suggest that the independent voice of the scholar could only have arisen within the confines of a new sort of town, one that included far more people than was the case with the traditional leftover communities of the Roman Empire. Expanding farther than the clerics and their market vendors, the new towns of the eleventh and twelfth centuries included individuals who were specialized in a particular craft: artisans who needed the town as much as the town needed them. Prior times included clerics who were not only men of prayer, but also land managers, judges, and administrators. And, these multi-tasking clerics were also writers, teachers, and scholars, from time to time. They were, quite literally, jacks of all trades, but masters of none. ${ }^{\mathrm{xxv}}$ 
Independent thought—at least of the sort we have seen in the millennia sincewas, thus, born, to a large extent, within larger communities that needed generalists to serve as clerics, of course, but also the growing needs of trained specialists within the townspeople. And with the increase in population came a desire to create a system of rules that dealt with those issues not of the church. A court system that replaced the clerical rule in some places, and worked along side it, immediately required a system of oversight: a hierarchy of standards administered by the "betters" of the community. Individuality may have risen in these easy centuries, but certainly along side that was the rise of "peers," those who would ensure that order and justice were preserved. Thus were the needs and standards of the community's secular rulers met and preserved.

By all accounts, these were difficult times. Travel between the growing — but still small-towns remained dangerous. This sense of uncertainty acted as a self-censor to the free-thinkers: promoting some (dangerous) ideas within the walls of these communities could be fatal, especially if one wished to remain behind the protective walls. A new class of scholars, whether teaching at the newly created universities in Bologna or Paris, had to ensure they did not run afoul not only of the church, but also the local secular rulers, the royal order of dukes and kings who held sway over the civic activities outside the monastery.

From one perspective, this is well-trod ground. Discussions of the influence of popes, kings, and other medieval power brokers on who was allowed to teach in and out of monasteries and courts are numerous and well-cited. The same can be said regarding the creation of universities, whether those that came to be in Paris or Bologna. While this is a familiar topic, ${ }^{\text {xxvi }}$ what is not discussed much is the actual process of what would 
result in the creation of a form of peer review in the period leading up to the Renaissance. How were works in the earlier parts of the first millennium assessed for their value and how did it come about?

For the scriptoria, publication in the Dark Ages and the era shortly after was defined as the creation of an accurate copy of the original work, letter by letter. The "scholarly" monk was judged by the accuracy of the transcription. The reward for the prelate was a valuable artifact, a Bible. The value to the transcriber was a reduction in the time he would spend in Purgatory, which the church promised the monk for the most accurate rendition. Exact accuracy in the replication of the existing Bible would ensure the best outcome for the transcriber. In a way, this exact duplication was a form of precise adherence to what was already known. To vary from the true version was to place one's soul (and possibly body) in danger. Only the strictest, most accurate copy of the work would be rewarded. It was, therefore, a form of extreme peer review, wherein the most worthy would receive the highest judgment— publication. No rewards for individualism. No rewards for anything other than a complete restating (transcription) of what was already the established "facts" as expressed in a Latin Bible. The act of peer review included only one act: bishops and archbishops judging the accuracy of the transcription. To vary in any way from the one true faith as expressed in the Bible would be judged as blasphemous. Creativity in transcription was not required. Accuracy was. This is not to suggest that a value was attached to the illuminations that were included in the margins of these transcription. But, again, the reward was a personal exchange between monk and prelate. 
For the "free-thinkers," such as those familiar to us who would appear centuries later-Kepler, Copernicus, Tycho, Galileo, and many others- the act of creation was an effort intended to better describe what they observed and, by that description, better understand the universe. But how did these earlier individuals_-and they certainly must have seen themselves as separate in their thinking and actions from the neighbors in their small towns - come to be revered in their own times? Did Erigena face a panel of peers in the Dark Ages, and, if so, of what composition and practice? We know little about either. What we do know is that these scholars were individuals, praised or damned. They set themselves apart by what the said and wrote, not unlike a modern scholar. But their works, even those they eventually recanted, were published first, then damned.

As to the answer of who acted as the prime decision maker over what was allowed and what was not, it may constitute nothing more than the local ruling regime of the day. This town-by-town set of standards is suggested to a great degree by the varying local political climate within one community versus another. This variance in what was deemed acceptable was never more apparent than in the case of the highly esteemed Erigena, given that was he was condemned as a blasphemer in cities other than his own. This excoriating of "competing" scholars was seemingly a common practice in the day. Each scholar-while working ostensibly for the local cleric — was subject to the opinions of church officiates in other regions. While holding forth in one community, the scholar could be (and was) banned in another.

This practice of irregular judgment should not seem so foreign to us today, given that some research is accepted in some quarters and rejected heartily in others. What may represent a significant variance in the practice of "peer" review in the first millennium 
may be that - at times - those in the position of endorsing one scholar over another, may not have been able to actually read the works of their most favored citizens. It is no secret that Charlemagne, while purchasing many books in his day, largely did so to use them as gifts to others: he was virtually illiterate.

However, it would be overreaching to suggest no review was conducted prior to the appearance of academic journals in the 17th Century. And, it would be equally ill advised to consider that all editors (and, at times, their herd of reviewers) of that day always understood what they were passing judgment upon. One has only to consider the much-later case of Einstein to conclude that even in the early Twentieth Century, editors were at times unaware of the value of the works presented to them for publication.

Those of the Seventeenth and Eighteenth Centuries resembled archivists more than the editors do today. As described by Shelley, these early editors were more in the business end of publishing, attempting to find presses willing to risk printing a work. The work itself might look and feel more like an archive ${ }^{\mathrm{xxvii}}$ or a book ${ }^{\mathrm{xxviii}}$ with a series of articles collected together. Such a compilation might have lead to the form of a journal and the role of an editor we see today.

Early journal editors were more instructive, attempting to set standards that new researchers seeking publication could follow. As noted by Rothberg in "To Set a Standard of Workmanship and Compel Men to Conform to It," editors such as John Franklin Jameson as of the American Historical Review sought to establish standards, and, by doing so, separate works from the ebb and flow of politics and other transient factors. ${ }^{\text {xxix }}$ Their efforts were intent on taming the unwieldy researchers, as Jameson himself would admit, a difficult task. The ultimate goal was to raise the quality of works 
and by doing so, raise the quality of the journals. And though we know little about the earliest editors, such as Henry Oldenburg, they must have appeared at least as interested in the financial and legal issues surrounding those journals as publishers are today. As noted by Snider, the role of editors and authors sustained each other.

The whole arena of editing scholarly journals, surprisingly enough, has not been subject to much sustained scrutiny or analysis. Editing, in my view, provides a readymade site for posing a range of theoretical questions about authorship, the status of texts, the materiality of printed objects, originality, copyright, collaboration, book reviewing, and so forth. Working as an editor will force the hand of anyone who prefers to ignore such matters as typography, layout, paper grades, and print runs—none of which will seem inconsequential to those called upon to make judgments on such matters. ${ }^{\mathrm{xxx}}$

\section{The Rise of the Reviewer}

The argument at hand for us to consider regarding scholarly works prior to the appearance of universities in Bologna and Paris, isn't whether they were censored, as suggested by Fuchs, ${ }^{\text {xxxi }}$ but whether they were reviewed by anyone. It is this author's argument that review did, in fact, occur, if only evidenced by the differing opinions that appeared and the varying condemnations that arose in various parts of Europe. Yes, scholarship took place. And, yes, some works were "corrected"— either by the author or some select clerics who acted as quasi-editors and sole publishers. Works were judged appropriate either prior to publication or after by church officials, usually those within the region of the author. Thus the works of Erasmus might be judged by Canterbury, while the works of Gallus by Rome. 
But, the very fact that review and correction occurred affirms the existence at those times of new ideas and the pressure to modify established beliefs. It would be untrue to suggest that no change in thinking occurred between the fall of Rome in the Fifth Century and the rise of the universities in the 12th Century. One need only consider the fusion of Roman law with Christian thinking that culminated-according to somewith the conversion of Emperor Constantine I. The hierarchical structure that delineated who was suitable for what ecclesiastical or secular office was based on the PseudoDionysian theology brought down with the absorption of the church into the Roman power grid. A place for everyone and everyone knowing one's place, all flowing from God's representative on earth: the Pope. This compares closely to the role of editors and reviewers of works submitted to our most august journals today.

This governmental grid of thinking was exemplified by Jerome's 4th Century translation of the Greek and Hebrew Bibles into Latin: the Vulgate Bible. Of course, as Europe moved into the latter part of the Middle Ages, this church-centered, churchdefined model for governing as a derivation of God to the Pope to the King would face changes, whether in Paris or on an island in the Thames called Runnymeade. City states grew into nations, lower nobility began to demand more certainty in the application of laws, and the power structure that had ruled all of Europe for centuries receded to a collection of regional (largely German) fiefdoms collectively known as the Holy Roman Empire.

What was largely theocratic governing was displaced as communities shifted more and more to control by secular powers. Yet of greater importance than the tracing the withering of the church's absolute restrictions on science was the rise of the concept 
of individuality. That one could hold a personal and unique thought in one's own head grew as the rising sense of security that one might actually keep one's head for such thoughts. Certainly, this is not to suggest that an average sheepherder in Scotland in the 9th Century could be expected to act as a free-thinker. It is to argue that without this rise in individuality, with all of its fits and starts, modern science could not have arisen.

The result of the crucible of fire that early scientists endured-as the Church's power faded and the power of the secular governments rose-was a growing society of scholars who shared parts of their works with others they identified as equally educated and dedicated free thinkers. The ebbing interests by the church away from scientific thinking did not, of course, immediately result in a free flow of information. Scientists were, at times, secretive in their techniques and their data (perhaps even more than today). Inventions, especially those involving optics used in astronomy, were not widely available on an open market. And, given the lack of what could readily be identified as publishing, works were not strictly "peer reviewed" in a modern sense.

That other scientists of the day would know of the precision of Tycho's work, for example, is evidence on its own that some form of review was taking place. No longer were the words of a thinker judged to be true by the mere imprint of a cleric. Scientists seeking to build models that explained the phenomenal world relied on the findings of others, but only if the measurements were shown to be accurate. Thus, the ideas of individuals could now be tested by other individuals seeking to affirm or reject the findings based on science alone. Peer review in this age of early science was subject to the same sort of politics and egos that many suggest plague modern science today. But, as we move forward to the Age of Reason, we must keep in mind that it was the rise of 
individuality — the independent thinker — that created the need for a peer review system. As individuals, a.k.a, researchers, became increasingly comfortable in expressing their ideas, the need grew to create a somewhat more transparent system of review that was not wholly part of the government or church. The influence of those within monarchies and papacies who predictably preferred all new ideas remained more closely concentric to existing, accepted thought faded. The sphere of influence shifted to those who recognized some value in new ideas that fell outside conventional thought. Some of this new flexibility was driven by political shifts in Europe in the 11th and 12th Centuries that pitted the church against various emperors, and the use of academics as pawns in jousts for power and control of kingdoms. Indeed, some have argued that the foundation of law in Western Culture was a direct result of these conflicts, in large part driven by the decision by the church to establish its own bureaucracy in the 11th and 12 Centuries. ${ }^{\text {xxxii }}$ Whether intended or not, the decision of the Church to focus its own canons, combined with the rise in the educated scholar, logically led to the individual, a freer thinker, a person with more independent thoughts. Edges were pushed, boundaries tested. The scientist was creating his own rules. What was lacking was a replacement scheme for the ebbing papal and civic power structure.

The rules of authorship in the Middle Ages were fairly simple: challenging the authorities (typically the Church) would lead to difficulties. But, as noted by Hannam, exactly who looked at what when and where has never been that clear. ${ }^{\text {xxxiii }}$ Certainly, in the case of Roger Bacon, failing to run a work by the appropriate authorities—in his case, the Franciscans leadership—prior to publication would land one in jail. But, this required peer review (that is, review prior to publication) was less common than the post- 
publication rebukes that more often than not resulted in a recant and a restoration of standing. In fact, the celebrated cases that resulted in heretical trials and executions were not the rule in most cases.

Unfortunately, however, the precise nature of the handling of materials in cases, such as that of Roger Bacon, remain vague at best. Even with Bacon, it apparently was his teaching that landed him in trouble, not his writings, as was likely the case with Cecco. With Cecco, famously burned at the state in the 14th Century, it was likely the stubborn nature of the scholar that contributed to his demise: his insistence in teaching astrology and casting Jesus' horoscope was a large part of a his spoken lectures and his ultimate demise.

The details are not at issue here. What we suggest is that the roots of peer review started with a desire on the part of the church to protect the its people, both physically and spiritually, from danger. The methods were, at times, more severe than those applied today; but who can say that being rejected is ever a welcome event? The lesson then was simple, so long as the scholar stayed away from anything that might have unallowable theological significance, it would be unlikely the Church would intervene. ${ }^{\mathrm{xxxiv}}$ The "scientific method" usually taken in this period in the 14th and 15th Centuries by scholars in their writings was to start with a question, then provide arguments on both sides before ending in an answer that conformed to the Church's view of the universe. Clever scholars might—as Thomas Carlyle was accused by critics of doing several centuries latermerely write in such a "dense and obscure language that a censor would never have the faintest idea what was actually being claimed."xxxv Argument over what was the alleged 
heretical work really meant were common, with the defendant claiming he had just been misunderstood.

Early criticism of published thought was as much a function of politics as it was a scholarly effort. Authors with strong ecumenical backing, such as Giles of Rome and Thomas Aquinas, were afforded more leeway, as the church faced internal struggles over the Christianization of assimilated Aristotle's ideas in the 13th and 14th Century. Reviews of published works were—in large part—a chapter in a long-term battle over the direction of the Church itself. Only in the latter part of the Middle Ages would a secular science arise that required prior-to-publication review by those outside the Church.

What we are left with is a mere idea that the form of peer review prior to publication probably occurred within cleric castes, such as brotherly orders, and were subject to the currents of religious thinking within the church at that time. Given that the publication process was undertaken by the authors themselves, such prior-to-publication approval must have been sought somewhat voluntarily by the writer. We suggest "somewhat" here only to note that an author that consistently at odds with the will of the Church would ultimately find himself an outcast. This act of rejection could result in a loss of secular support, even expulsion from a community.

The rise of secular humanists, starting with Francesco Petrarch in the 14th Century, through to Francis Bacon in the 17th Century, was punctuated by a growing independence from the Church. It also saw the rebirth of the individual, suppressed by the caste system in the latter years of the Roman Empire and feudalism in the Middle Ages. Denial of the self was taught as the surest path of salvation, along with self-abnegation and self-annihilation. As noted by Kreis, "The period from the 14th century to the 17th 
worked in favor of the general emancipation of the individual. City-states of northern Italy had come in contact with the diverse customs of the East, and gradually permitted expression in matters of taste and dress...Individualism and the instinct of curiosity were vigorously cultivated. Honest doubt began to replace unreasoning faith." ${ }^{\text {xxxvi }}$

Kreis goes on to link this rise in humanism (and its ancillary, individualism) to change in religious beliefs and political systems. I would suggest that without the recreation of the concept of the individual, we would have no peer review. Without the boldest of a single person to submit their works to the judgment of other prior to publication, the very nature of scientific inquiry would have taken a vastly different path. Individual imagination has driven great ideas. The review of ideas by groups-whether by bishops or academics—has attempted to weed out the group—defined "worst" while preserving the best.

\section{Conclusions}

The resulting climate in Europe by the time of the Guttenberg press was one of learning, sharing, and collaboration on a scale unheard of just a few centuries earlier. The Scientific Method, along with peer review, can be traced directly back to the concept of an individual attempting to describe the universe not as a subset of current thought, but as an expression of inner belief based on observation and reflection. Some of the greatest leaps forward in science were the result of groups of researchers focused on the former of these two: a method that comprised experimentation, observation, and repetition. At the same time, other massive leaps forward can be traced to the act of a single individual applying more reflection to a question than pure scientific observation: the discovery of 
air, the discovery of gravity, the atom, the theory of relativity. The beliefs expressed by an individual through herself and her science still may require oversight by a panel of peers, but there can be little doubt that without the spirit of individuality that arose in the latter part of the Middle Ages, the form of the review would largely be vastly different and, perhaps, unnecessary. Groups of scientists could argue more forcefully for their findings than a single individual even today, much as a panel of peers can argue a research paper needs more work.

So, we have at least one of the major necessities of modern science and modern peer review, the individual. Perhaps what we need now is a more effective method of distribution of ideas, more sharing of thinking, and more participation of scientists in the conversation of scholarly works: the printing press. We have progressed only slightly, shifting the weight of measurement from clerics to academics, both groups holding unvarying sets of beliefs, both assured in their correctness. The flow from the judgments of the works of Bacon and Cecco to more recent academic decisions is unbroken. The Church applied its own form of logic, just as scholars do the same today. Punishments may have changed over time, but the resistance to change has varied only slightly. The desire to maintain the status quo is ever present, no matter what field, no matter what college. What we have record of peer review prior to Guttenberg may not match what we think of our system. We may remain resistant that the church did was "real" peer review. But we cannot deny that what would follow in the time since Guttenberg had some rudimentary elements created and fostered within our Western Civilization many centuries earlier. 
The Church method of review allowed what we seemingly cannot tolerate today:

publication then criticism. If we wish to suggest that as an academy of thinkers we are more tolerant than the Church in the Dark Ages, can we now take the step of allowing publication then applying critiques using the tools of new media?

\section{End Notes}

\footnotetext{
${ }^{\text {i }}$ Douglas P. Peters and Stephen J. Ceci, 'Peer-Review Practices of Psychological Journals: The Fate of Publishing Articles, Submitted again,' The Behavioral and Brain Sciences, 5 (1982), 187-255, 187.

ii Peters and Ceci, 'Peer-Review Practices of Psychological Journals: The Fate of Publishing Articles, Submitted again,' 190.

iii C. Wennerás and A. Wold, 'Nepotism and sexism in peer review,' in M. Wyer, D. Giesman, M. Barbercheck, H. Ozturk and M. Wayne, eds., Women, science, and technology (New York: Routledge 2001): 46-52.

iv Wennerás and Wold, 'Nepotism and sexism in peer review,' 52.

v J. Dacey, 'Peer reviewers accused of nepotism,' Physics World, (February 2, 2010), available at http://physicsworld.com/blog/2010/02/researcher_accuses_peer-review.html.

${ }^{v i}$ R. Dalton, 'Peers Under Pressure,' Nature, 413 (September 13, 2001): 102-103.

vii Dalton, 'Peers Under Pressure,' 103.

viii M.J. Mahoney, 'Publication prejudices: An experimental study of confirmatory bias in the peer review system,' Cognitive Therapy and Research, 1,1 (1977): 161-175.

${ }^{\text {ix }}$ B.D. Neff, and J.D. Olden, 'Is peer review a game of chance?' Bioscience, 56, 4 (2006): 333-340.

${ }^{x}$ B.D. Neff, and J.D. Olden, 'Is peer review a game of chance?' 333.

${ }^{x i}$ Juan Miguel Companario, 'Rejecting and Resisting Nobel Class Discoveries: Accounts by Nobel Laureates," Scientometrics, 81,2 (2009): 549-565.

xii Planck, Max. 'Scientific Autobiography and Other Papers,' trans. F. Gaynor (New York, 1949): 33-34, (as cited in T.S. Kuhn, The Structure of Scientific Revolutions, University of Chicago Press, 1962).

xiii Companario, "Rejecting and Resisting Nobel Class Discoveries,' 549.

${ }^{\text {xiv }}$ Companario, "Rejecting and Resisting Nobel Class Discoveries,' 558.

${ }^{x v}$ Companario, "Rejecting and Resisting Nobel Class Discoveries,' 558.

${ }^{x v i}$ R. Zghal, 'Science, technology and society: What makes the culture of innovation,' in G. Zawdie and A. Djeflat, eds., Technology and transition: The Maghreb at the crossroads (London: Cass 1996).
} 
${ }^{x v i i}$ D.E. Chubin and E.J. Hackett, Peerless science: Peer review and U.S. science policy (Albany, NY: State University of New York Press 1990): 97.

${ }^{\text {xviii }}$ E. Buringh and J. Van Zanden, 'Charting the "rise of the west": Manuscripts and printed books in Europe, A long-term perspective from the sixth through eighteenth centuries,' The Journal of Economic History, 69,2 (2009): 409. D.S. Clark, 'The medieval origins of modern legal education between church and state.' American Journal of Comparative Law, 35, 44 (1987): 653-719. J. Hannam, Medieval science, the church, and universities (2009), available at http://www.bede.org.uk/university.htm. J.E. Sandys, J. E. (1906). A history of classical scholarship: From the sixth century B.C. to the end of the middle ages (London: Cambridge University Press 1906).

${ }^{x i x}$ J. Le Goff, Intellectuals in the middle ages, (Cambridge, MA: Blackwell 1993).

${ }^{\mathrm{xx}}$ S. Kreis, Renaissance humanism (November 7, 2008) available at http://www.historyguide.org/intellect/humanism.html

${ }_{\mathrm{xxi}} \mathrm{S}$. Kreis, Renaissance humanism.

xxii J. Hannam, Medieval science, the church, and universities.

xxiii J. Le Goff, Intellectuals in the middle ages, 6.

xxiv J. Le Goff, Intellectuals in the middle ages, 9.

${ }^{\mathrm{xxv}} \mathrm{J}$. Le Goff, Intellectuals in the middle ages.

${ }^{x x v i}$ D.S. Clark, 'The medieval origins of modern legal education between church and state.' R. F. Fuchs, 'Academic Freedom-Its basic philosophy, function, and history,' Law and Contemporary Problems, 28, 3 (1963): 431-446. S. Fuhrman, and M. Lazeson, The public schools, ed. K.H. Jamieson (New York: Oxford University Press 2005). R. Halse and G.L. Lilien, 'The ombudsman: Academic research in MS/OR: Science or trivial pusuit,' Interfaces, 16, 3 (1986): 41-48. R. Hofstadter and W.P. Metzger, The development of academic freedom in the united states, (New York: Columbia University Press 1955). L. Joughin, L., ed., Academic freedom and tenure (Second ed.), (Madison, WI: University of Wisconsin Press 1969). W.R. Keast and J.W.J. Macy, eds, Faculty tenure, (London: American Association of University Professors, Association of American Colleges and Jossey-Bass, Inc. 1973). W. Plater, 'Future work,' Change, 27 (May/June 1995): 22-33. N.W. Hamilton, Academic ethics: Problems and materials on professional conduct and shared governance, (Westport, CT: American Council on Education/Praeger 2002).

${ }^{x x v i i}$ F. Shelley, 'Ebenezer hazard: America's first historical editor,' The William and Mary Quarterly, 12, 1 (1955): 44-73, available at http://www.jstor.org/stable/1923095.

${ }^{x x v i i i}$ A. Snider, 'What is an editor?' Iowa Journal of Cultural Studies, 12/13 (2010): 169172.

${ }^{\text {xxix }}$ Morey D. Rothberg, 'To Set a Standard of Workmanship and Compel Men to Conform to It: John Franklin Jameson as Editor of the American Historical Review,' The American Historical Review, 89, 4 (1984): 957.

${ }^{x x x}$ A. Snider, 'What is an editor?'

${ }^{x x x i}$ R. F. Fuchs, 'Academic Freedom-Its basic philosophy, function, and history.'

${ }^{x x x i i}$ D. Berman, Law and revolution: The formation of the western legal tradition, (Boston: Harvard University Press 1983).

xxxiii J. Hannam, Medieval science, the church, and universities.

xxxiv J. Hannam, Medieval science, the church, and universities. 
${ }^{\mathrm{xxxv}} \mathrm{J}$. Hannam, Medieval science, the church, and universities.

${ }^{x x x v i}$ S. Kreis, Renaissance humanism. 